UDC: 027.7:[659.144.1:028]

MIAMLINA A. V.

Free scientist (Dnipro, Ukraine), e-mail: tomanagemedia@gmail.com,

ORCID 0000-0001-8981-0170

\title{
MARKETING COMMUNICATIONS: READING PROMOTION PROGRAMS IN ACADEMIC LIBRARIES
}

Objective. The article covers different forms of communication between library staff and its users including reading promotion. It is rather effective for libraries to communicate with the target audience. Nowadays libraries need to communicate with customers and academic libraries are not in the exception list. Academic library staff need to communicate and build strong relations with students, professors and staff of university. Target audience may be informed about the library, support of users or different events that take place in library space. Methods. Based on the analysis of scientific research, a list of potential communication channels has been identified. Library messages and reading promotion campaigns were also analyzed. Results. Part of library communication should be devoted to book reading promotion and reading programs. Library staff need to get acquainted with programming and marketing, because without this knowledge it is hard to fulfill main activity. Marketing is everywhere today, even in academic library activity. The article describes the main elements of communication between the academic library and the user: messages, channels, target audience and gives examples of information and advertising campaigns conducted by different libraries. Conclusions. Reading promotion programs maybe part of common library communication. Modern libraries start to communicate with their users, promote reading books and educate readers. It can be done with a budget on promotion and without it.

Keywords: academic library; communications; information campaign of the academic libraries; reading promotion; campaigns to support reading books in university libraries; book advertising

\section{Introduction}

Academic library play a critical role in connecting community members to vital resources and programs, now more than ever.

Scientific library in the university help students to study and write bachelor's or master's thesis.

Communication with readers, main target audience of library, is in urgent need for modern library. Academic library also need to build strong communication with readers. Even if it is students and even if they will change every 2-4 years.

How academic libraries communicate with customers and connect with their community?

\section{Methods}

In this study secondary data analysis and research reports were used to create list of potential communication, channels, ideas for communication campaigns and messages. Analysis of librarian communication messages and book reading promotion was made. In addition, common scheme of communication was implemented to academic library communication process with users.

\section{Results and Discussion}

Communication scheme for academic library looks like this (based on Roman Jakobson's scheme): sender - message - receiver - channel - code - context.

- Sender of the message (academic library) 
- Message (visit academic library, read more books provided by library, use services provided by library)

- Receivers (students, lecturers, professors, faculty members and staff)

List of possible channels of communication for academic library:

- web site (articles, news, blog)

- social media

- academic newspaper, student radio or TV

- graffiti (outdoor and indoor, that are so popular in European universities)

- posters

- calendars

- souvenirs

The survey "US Public Libraries: Marketing and Communications Landscape" mentioned such communication channels that can be used by library and may be suitable for academic libraries:

- printed material in the library

- social media

- library's website

- library events

- local communication events

- local media

- e-mail messages (for site subscribers and those who have a library card) (US Public Libraries: Marketing and Communications Landscape, 2018).

Great example of engaging followers and new young readers was shown by New York Public Library. In 2018 the communication campaign "Insta Novels" was set. Special format of engagement was Instagram Stories, fast format. Famous novels were presented in several second video story. Among first novels were "Alice in Wonderland", "The Metamorphosis". By the way, this novels often used by advertising agencies while launching advertising campaign for bookshops for creating narrations (Freberg, 2020).

E-mails as an effective way of communication and good strategy can use such target messages: library card is going to expire, we've missed you.

Another way to communicate with readers is newsletters. It is important form of communication mentioned in "Communication in the Library: the Role of Librarians" (Martins, Cortês, Graça, 2011).

Target audience of the messages sent by academic libraries:

- students (first year bachelor students, graduate students, master students)

- lecturers and professors

- staff and faculty members.

Students are rather specific audience for communion. First of all, they have studies at university and obtain profession and experience for further activity. Students need to create presentations, prepare individual tasks, participate in scientific conferences and publish thesis, write bachelor's or master's thesis.

From the other side, students are young people (17-25 years old) and they are very curious and open to new information, new facts and knowledge. This means that they are a very good audience for library communication and reading promotion.

Professors and staff also can be participants of different reading challenges launched by academic library staff.

Academic libraries can use a variety of messages, for example: 
- get a library card

- visit library

- read books

- read special book (written by university professor or graduate)

- read more

- read scientific books

- read classical texts

- read book wrote by famous scientists

- library is full of surprise

- read for fun

- read books to know more facts

- read books to pass exams

- read book to be smart

- promotion of reading advantages

- visit new web-site

- order books with new online service (in case it is available)

Target message will be working in the best way when it give students benefit they want, for example "10 books to help you learn more about...". Keeping balance between too much and not enough information from library is one of the main task in communication strategy.

Main goal of communication campaigns and objectives:

-increase library usage

-promote books

-promote advantages of reading

-give example of positive library usage (for further model)

- increase awareness of library

- increase use of library material

- increase participation in library events and traffic to library

- promote the value of library

- connection with community (students, professors and academic staff)

Some libraries give us bright examples of creative communication with readers. For example, look at advertising created for Czech Library Association "Read It Before Hollywood Does" with Jane Air, The Old Man and the Sea. Milwaukee Public Library provide great example of advertising campaign that mark advantage of library: "Turn your face to the book", "You could be Reading", "140 characters? Try millions". American Library Association also has launched a series of events to promote libraries and reading (banned book week, teens read) and supported this event with powerful posters spread all over the country (Miamlina, 2016). Madrid Book Publishers Association also launched powerful campaigns in order to communicate with the readers. The most powerful was about "Reading stimulates your imagination" with Sherlock and Cyrano, as well as futuristic ad campaign with the slogan "The more you read, the more you see" that shows the power of books and reading.

According to research data in US Public Libraries: Marketing and Communications Landscape (2018) $40 \%$ of public libraries have a communication strategy and $25 \%$ have marketing professionals or staff. Madrid Book Publishers Association cooperates with the world famous advertising agency "Grey", regional office in Madrid (Spain). New York Public Library cooperated with the advertising agency "Mother".

But it is not important to have budget or cooperate with famous marketing agency as communication starts from library and staff. 
By the way, some communications may be classified as public service announcement, communications that promote public interests, for example reading promotion. Such communication are placed free (public TV, radio, outdoor). Of course, it is good to have a budget for promotion and communication. But reality is that librarians, like real superheroes, need to be acquainted with marketing and even programming, because without such skills and knowledge it is hard to fulfill new main activity. It is making the most of limited resources with no marketing budget.

\section{Conclusions}

10-20 years ago, the library was a building where users went to get the documents and the information they needed and had access to the expertise of specialized professionals. And now inspiration starts in the library, because library help users read, learn and connect. So, let us communicate with library users and promote library service and reading books with powerful information campaigns. Design of information and advertising message will be the object of another article.

\section{REFERENCES}

US Public Libraries: Marketing and Communications Landscape. (2018). Retrieved from: https://www.oclc.org/content/dam/research/publications/2018/216084_2018_Public_Library_Mar keting_Report.pdf (in English)

Freberg, K. (2020). Discovering Public Relations. An Introduction to Creative and Strategic Practices. Thousand Oaks: SAGE Publications, Inc. California. (in English)

Martins, A. Cortês, C., \& Graça, G. (2011). Communication in the Library: The Role of Librarians May. FESABID 2011: 12th Spanish Documentation Conference (25 th -27 th of May 2011, Malaga).

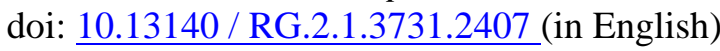

Miamlina, A. V. (2016). Marketynh Biblioteky Vyshchoho Navchalnoho Zakladu. Biblioteka Universytetu Na Novomu Etapi Rozvytku Sotsialnykh Komunikatsii. Materialy III Mizhnarodnoi NaukovoPraktychnoi Konferentsii (December 1-2 2016, Dnipro), 210-219. doi: 10.6084/m9.figshare.4294826. (in Ukraine)

МЯМЛІНА А. В.

Вільний вчений (Дніпро, Україна), e-mail: tomanagemedia@ gmail.com, ORCID 0000-0001-8981-0170

\section{МАРКЕТИНГОВІ КОМУНІКАЦІЇ: ПРОГРАМИ ПРОМОЦЇ̈ ЧИТАННЯ КНИГ В УНІВЕРСИТЕТСЬКИХ БІБЛІОТЕКАХ}

Objective. Стаття висвітлює різні форми спілкування між співробітниками бібліотеки та іï користувачами, включаючи просування читання. Для бібліотек досить ефективно спілкуватися з цільовою аудиторією. В даний час бібліотекам необхідно спілкуватися 3 клієнтами, і академічні бібліотеки не $є$ винятком. Співробітникам академічної бібліотеки необхідно вести діалог і будувати міцні відносини зі студентами, викладачами та співробітниками університету. Цільова аудиторія може бути проінформована про бібліотеку, підтримку нею користувачів або різні події, що відбуваються в бібліотечному просторі. Methods. На основі проведеного аналізу наукових досліджень визначено список потенційних каналів комунікацій. Також було проаналізовано повідомлення бібліотек та кампанії промоції читання. Results. Частина бібліотечної комунікації повинна бути присвячена популяризації читання книг i програм читання. Співробітникам бібліотеки необхідно ознайомитися з програмуванням і маркетингом, тому що без цих знань складно виконувати основну діяльність. Маркетинг сьогодні присутній скрізь, навіть в роботі академічній 
бібліотеки. У статті описані основні елементи комунікації академічної бібліотеки і користувача: повідомлення, канали, цільова аудиторія та наведені приклади інформаційних та рекламних кампаній, що проводяться різними бібліотеками. Conclusions. Заохочувальні читання можуть бути частиною загального бібліотечного спілкування. Сучасні бібліотеки починають спілкуватися зі своїми користувачами, заохочують їх до читання. Це можна зробити з бюджетом на просування і без нього.

Ключові слова: університетські бібліотеки; комунікації; інформаційні кампанії університетських бібліотек; промоція читання; кампанії на підтримку читання книг в університетських бібліотеках; реклама книги 